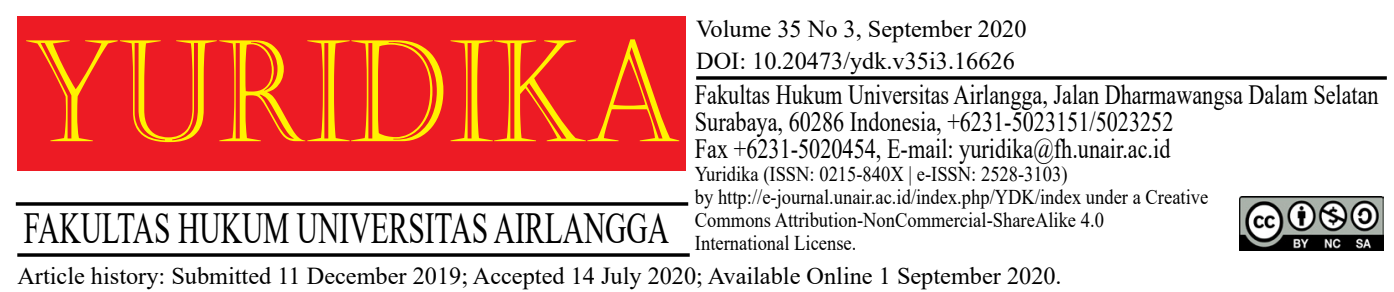

\title{
Prohibition of Child pornography: Enhancing Child Protection in Indonesia
}

\author{
Zendy Wulan Ayu Widhi Prameswari \\ Zendy@fh.unair.ac.id \\ Airlangga University
}

\begin{abstract}
As many other countries in the world, Indonesia has serious problems with child pornography. The problems linked with the child pornography exist in Indonesia, involving both male and female children. In 2008, Law Number 44/2008 on Pornography was enacted. With regard to the widespread distribution and accessibility of child pornography through the Internet, Indonesia also has Law Number 11/2008 and its revision on Electronic Information and Transaction. At the international level, Indonesia has ratified the Convention on the Rights of the Child (CRC). Furthermore, in 2012, Indonesia ratified the Optional Protocol to the Convention on the Rights of the Child on the Sale of Children, Child Prostitution and Child Pornography (OPSC). However, based on data from the Indonesian Child Protection Commission (Komisi Perlindungan Anak Indonesia/KPAI) from 2017 to 2019 there were 1940 cases of child pornography and cybercrime reported. The cases of child pornography are still increasing and seems impossible to stop. This paper will scrutinize how the existing Indonesian law concerning prohibition of child pornography protects the children. It will also examine whether the law are in compliance with the OPSC. This paper is a doctrinal research using statute, conceptual and comparative approaches. The existing Indonesian law will be compared with the OPSC. The study will show some of the compatibility issues of Indonesian respective national law with the OPSC. On the basis of the findings, the last part of the study will provide recommendations on how Indonesia shall enhance the fight against child pornography.
\end{abstract}

Keywords: OPSC; CRC; prohibition of child pornography; Indonesian law; children's rights.

\section{Introduction}

Sexual violence against children is a children's rights violation. Yet so many countries facing it in its various forms. The forms can be sexual abuse, harassment, 
rape or sexual exploitation in prostitution or pornography. ${ }^{1}$ They do not always involve direct touching and can occur in any setting, for instance groomed online by an older man and lured into sex acts, exhibitionism or producing indecent images; ${ }^{2}$ and in some cases where the children become the victims of child pornography.

Child pornography has been noticed as a serious issue which these times is getting more and more difficult to track. In 1960's, child pornography started to be made mainly in magazines and films. In 1970's, child pornography was considered as an inconceivable peril to children and in some countries like England, it was against the law. Nowadays, the technology like computers, internet, emails, external storage devices have made it easy for the child pornography makers to do criminal activities and hide effectively from the law enforcement agencies. ${ }^{3}$ Child pornography has harmful effects on children because it exploits children for sexual and commercial purposes. It has serious short and long term consequences not only to the children's body, but also their mind. ${ }^{4}$

As the most inclusive international instrument to protect and promote children's rights, the Convention on the Rights of the Child (hereinafter 'CRC') guarantees the protection of children's rights as well as from all forms of abuse, violence, neglect and exploitation. ${ }^{5}$ The CRC through Article 34 obliges States Parties to protect children from all forms of sexual exploitation and sexual abuse. To reach these goals, the States Parties shall in particular take all appropriate measures including national, bilateral and multilateral to prevent the inducement or coercion of a child to engage in any unlawful sexual activity, the exploitative use

1 UNICEF, 'Sexual Violence against Children' (UNICEF, 2018) <https://www.unicef.org/ protection/57929_58006.html> accessed 17 June 2020.

2 Lorraine Radford, [et.,al.], Preventing and Responding to Child Sexual Abuse and Exploitation: Evidence Review (UNICEF 2015).[8].

3 Suzanne Ost, Child Pornography and Sexual Grooming: Legal and Social Responses (Cambridge University Press 2009).[25].

4 Combating "Child Abuse Images" Through Committed, Transversal And Internationally Coordinated Action, Report of the Social, Health and Family Affairs Committee, 2011 in Mihaela Astinova, The Crime of Child Pornography: European Legislative and Police Coop (International and European Public Law Master Thesis, Tilburg University 2013).[7].

5 UNICEF, Handbook on the Optional Protocol on the Sale of Children, Child Prostitution and Child Pornography (UNICEF IRC 2009).[1]. 
of children in prostitution or other unlawful sexual practices, and the exploitative use of children in pornographic performances and materials. Article 39 of the CRC requires States Parties to take all relevant actions to advocate recovery and social reintegration for both physical and psychological of a child victim of any form of neglect, exploitation, or abuse; torture or any other form of cruel, inhuman or degrading treatment or punishment; or armed conflicts. Such recovery and reintegration shall take place in an environment that fosters the health, self-respect and dignity of child victims.

In 1994, the Committee on the Rights of the Child (hereinafter 'Committee') concerned the decision of the Commission on Human Rights to set up an openended working group to arrange guidelines for a possible draft optional protocol to the Convention on the sale of children, child prostitution and child pornography, as well as essential measures needed to prevent and eliminate them. The growing availability of child pornography on the internet and other social media was one of the main concerns of the OPSC drafting. ${ }^{6}$ Six years later, in 2000 the United Nations General Assembly adopted the Optional Protocol to the Convention on the Rights of the Child on the Sale of Children, Child Prostitution and Child Pornography (hereinafter 'OPSC'). ${ }^{7}$ By 2020 , it has been ratified by 176 states including Indonesia. ${ }^{8}$

At the international level, Indonesia has ratified both the CRC and the OPSC as the main international instruments to combat child pornography. While at the national level, there are some domestic laws which are used by Indonesia to fight pornography and protect the children e.g. Indonesian Criminal Code, Law Number 13 Year 2003 on Labour (hereinafter 'Labour Law'), Law Number 11 Year 2008 on Electronic Information and Transaction and its revision (hereinafter

\footnotetext{
6 Trevor Buck, International Child Law (Routledge 2014).[108].

7 UNICEF, Implementation Handbook for the Convention on the Rights of the Child (UNICEF Regional Ofice for Europe 2007).[514].

8 United Nations Treaty Collection, 'Human Right : 11. c Optional Protocol to the Convention on the Rights of the Child on the Sale of Children, Child Prostitution and Child Pornography' (United Nations Treaty Collection, 2000) <https://treaties.un.org/Pages/ViewDetails.aspx?s$\mathrm{rc}=$ TREATY\&mtdsg_no=IV-11-c\&chapter=4\&clang=_en $>$ accessed 14 May 2020.
} 
'Electronic Information and Transaction Law'), Law Number 44 Year 2008 on Pornography (hereinafter 'Pornography Law'), Law Number 23 Year 2002 on Child Protection and its revisions (hereinafter 'Child Protection Law'). However, based on data from the Indonesian Child Protection Commission (Komisi Perlindungan Anak Indonesia/KPAI), Minister of Women's Empowerment and Child Protection (PPPA) Bintang Puspayoga said the number of cases of child complaints related to pornography and cybercrime (victims and perpetrators) reached 1,940 children from 2017 to $2019 .{ }^{9}$ The cases of child pornography are still increasing and according to KPAI, child pornography and cybercrime cases are in the big three cases reported involving children. ${ }^{10}$

This paper will scrutinize how the existing Indonesian laws concerning prohibition of child pornography protects the children. It will also examine whether the laws are in compliance with the OPSC. This paper employs the doctrinal research methodology using statute, conceptual and comparative approaches. It involves the study of law 'in the book' and is concerned with the formulation of legal 'doctrines' through the analysis of legal rules. Furthermore, the existing Indonesian laws will be compared with the OPSC. The study will show some of the compatibility issues of Indonesian respective national law with the OPSC. On the basis of the findings, the last part of the study will provide some recommendations on how Indonesia shall enhance the fight against child pornography. In addition, until this study is being done, Indonesia has not submitted the initial report to the Committee containing comprehensive information on the measures it has taken to implement the provisions of the OPSC. ${ }^{11}$ By doing the study, this research will serve some

\footnotetext{
9 Jnp/Dal, 'KPAI: 1.940 Anak Jadi Korban Kejahatan Online Sejak 2017-2019' (KPAI: 1,940 Children Become Victims of Cybercrimes within 2017-2019)' (cnnindonesia, 2020) <https:// www.cnnindonesia.com/teknologi/20200210131134-185-473240/kpai-1940-anak-jadi-korban-kejahatan-online-sejak-2017-2019>. accessed 17 June 2020.

10 Maikada Harjono, 'KPAI: Pornografi Dan Cyber Crime Masuk Tiga Besar Pengaduan Anak' (KPAI: Pornography And Cybercrimes Are In The Big Three Cases Reported Involving Children)' (kominfo, 2020) <https://aptika.kominfo.go.id/2020/02/kpai-pornografi-dan-cyber-crimemasuk-tiga-besar-pengaduan-anak/> . accessed 17 June 2020.

${ }^{11}$ United Nation Human Rights‘UN Treaty Body Database’.( United Nation Human Rights,) $<$ https://tbinternet.ohchr.org/_layouts/15/TreatyBodyExternal/TBSearch.aspx >accessed 17 June 2020 .
} 
considerations for the Indonesian Government when the Indonesian Government prepares the initial report.

\section{The Indonesian Law Concerning Prohibition of Child Pornography in the} Light of the Optional Protocol on the Sale of Children, Child Prostitution and Child Pornography

With rising reports of exploitation experienced by children online, the use of the Internet by individuals who seek to commence contact with children for sexual purposes is of concern and requires attention. ${ }^{12}$ By the United Nations General Assembly unanimously adopted the CRC in 1989, the international community committed to protect children from exploitation and abuse, and to support the restoration of children to normalcy when victimization does occur. The provisions stipulated by the CRC were expanded into far more detail in the OPSC. ${ }^{13}$

Article 1 of the OPSC guarantees that "States Parties shall prohibit the sale of children, child prostitution and child pornography as provided for by the present Protocol." Article 2 gives the description of the conducts prohibited in the OPSC. Article 2(c) of the OPSC defines child pornography as "any representation, by whatever means, of a child engaged in real or simulated explicit sexual activities or any representation of the sexual parts of a child for primarily sexual purposes." This article must be considered together with Article 3, which categorizes acts that, as a minimum, should be "fully covered" by the criminal or penal legislation of States Parties. ${ }^{14}$ Furthermore, Article 3 provides that "[e]ach State Party shall make these offences punishable by appropriate penalties that take into account their grave nature."

While the CRC, as well as OPSC, are framed in universal terms, the concepts of advantage, misuse, flexibility and wellbeing are also culturally specific. Therefore,

\footnotetext{
12 Juliane A. Kloess, [et.,al.], 'Online Child Sexual Exploitation: Prevalence, Process, and Offender Characteristics' (2014) 15 Trauma, Violence, \& Abuse. [126-139].

${ }_{13}$ Warren Binford, 'A Global Survey of Country Efforts to Ensure Compensation for Child Pornography Victims’ (2015) 13 Ohio State Journal of Criminal Law. [37-65].

${ }_{14}$ UNICEF, Handbook on the Optional Protocol on the Sale of Children, Child Prostitution and Child Pornography (n 5).[9].
} 
for research and policy communities, advancing children's rights in the digital era must be a task that is conceived universally and locally. ${ }^{15}$

In the context of Indonesia, Article 283 of Indonesian Criminal Code prohibits the offering and disseminating of writing, images or objects that violate decency, as well as tools to prevent or abort the pregnancy to someone who is not yet an adult, and who is known or should be suspected that in general he or she has not been seventeen years old. The perpetrator will be threatened with a maximum imprisonment of nine months or a fine no more than nine thousand Indonesian Rupiah (IDR). The penalties for the offenders are not severe. In addition, the provision does not meet the stipulations of the OPSC since it does not address child pornography as the content of the representations. ${ }^{16}$ The Indonesian Criminal Code does not have the provision regarding child pornography as addressed by the OPSC.

In 2008, Pornography Law was enacted. ${ }^{17}$ It defines a child as every human being below the age of 18 years. ${ }^{18}$ It has the same provisions as Indonesian Criminal Code which prohibits the offering and disseminating of any representation which violates decency to children. ${ }^{19}$ The perpetrator will be sentenced to a minimum of 6 (six) months and a maximum of 6 (six) years imprisonment and / or a fine of at least two hundred and fifty million IDR and a maximum of three billion IDR. ${ }^{20}$ Furthermore, this law through Article 4 (1)(f) also criminalizes the producing, creating, reproducing, duplicating, distributing, disseminating, broadcasting,

15 Sonia Livingstone and Monica E. Bulger, 'A Global Research Agenda for Children's Rights in the Digital Age' (2014) 8 Journal of Children and Media. [317-335].

${ }_{16}$ Zendy Prameswari, 'Prohibition of Sale of Children: Legal Consequences of the Ratification of the Optional Protocol on the Sale of Children, Child Prostitution and Child Pornography by Indonesia.' [2011] Master Thesis, International Human Rights and Humanitarian Law Program, European University Viadrina Frankfurt (Oder)."http://www.mendeley.com/documents/?uuid=042 b2616-cb50-473e-8af1-6d85fa490737"]\}],"mendeley": ‘“formattedCitation":"Zendy Prameswari, 'Prohibition of Sale of Children: Legal Consequences of the Ratification of the Optional Protocol on the Sale of Children, Child Prostitution and Child Pornography by Indonesia.' [2011] Master Thesis, International Human Rights and Humanitarian Law Program, European University Viadrina Frankfurt (Oder [30].

17 Entered into force on 26 November 2008

18 Article 1 point 4.

19 Articles 12 and 15.

${ }^{20}$ Article 38. 
importing, exporting, offering, selling or providing any representation which explicitly contains child pornography. The perpetrator will be sentenced to a minimum of 6 (six) months and a maximum of 12 (twelve) years imprisonment and/or a fine of at least two hundred and fifty million IDR and a maximum of six billion IDR. ${ }^{21}$

According to Indonesian pornography law, the involving of children in any activity relating to material containing pornography will be punished more severely with $1 / 3$ (one third) of the maximum criminal penalties. ${ }^{22}$ Unfortunately, it does not have the provision which define child pornography. Pornography Law only defines pornography as 'pictures, sketches, illustrations, photographs, writings, voices, sounds, motion pictures, animations, cartoons, conversations, gestures, or any representation, through media and/or performances in public, which contains obscenity or sexual exploitation against morality in society. ${ }^{23}$ However, the definition of child pornography precisely given by the explanatory note of the Article 4 (1f). The explanatory note defines child pornography as any form of pornography involving children or involving adults who play or act like children.

Compared to the definition provided by the OPSC, the definition given by the explanatory note of the Article 4 (1)(f) does not meet the requirement since it does not address whether the representation of the "simulated sexual activities of the children" is included. To produce, create, reproduce, duplicate, distribute, disseminate, broadcast, import, export, offer, sell or provide any representation of a simulated sexual activities of the children for primarily sexual purposes, the offender does not need to involve them. As the rapid development of technology where the computer became more forceful, and more economical, pedophiles also quickly recognized cyberspace (and the advantage of its anonymity) to be a prospering marketplace for child pornography. By using digital-imaging technology,

\footnotetext{
${ }^{21}$ Article 29.

22 Articles 11 and 37.

${ }^{23}$ Article 1 point 1.
} 
"real" children are no longer required to create child pornography. ${ }^{24}$ The Internet has designed bizarre spaces for adults and youths to explore their sexual statuses, however it should also design new ways for the law to monitor and punish a diverse range of taboo sexual communication..$^{25}$

Yet, the explanatory note of the Article 4 (1)(f) explains that what is meant by "creating" is not included if it is for self- interest purposes. Along this lines, the Indonesia pornography law allows the creating of child pornography as long as it is for self- interest purposes no matter what, including for sexual purposes. While the OPSC explicitly addresses that one of the element of child pornography is for primarily sexual purposes.

Labour Law makes it an offence to use children to produce pornography or for pornographic performances. ${ }^{26}$ Article 67A of Child Protection Law regulates that every one must protect children from the influences of pornography and prevent children's access to information that contains pornography. In addition, Article 59(2)(f) and 59A of Child Protection Law argue that children who are victims of pornography must receive special protection which carried out through:

a. rapid handling, including treatment and/or rehabilitation physically, psychologically, and socially, and prevention of diseases and other health problems;

b. psychosocial assistance during treatment until recovery;

c. provision of social assistance for children who come from poor families; and

d. providing protection and assistance to every judicial process.

Unfortunately, Indonesian law lacks of definition of child pornography. This might allow several crimes which could be included in the category of child pornography based on the OPSC cannot be criminalized under national law. According to UNICEF, some national legislations give the meaning of key terms such as sexual exploitation too narrowly and do not reflect the full scope of the international definitions. The importance of the conceptual clarity is for ensuring

\footnotetext{
${ }^{24}$ Wade T. Anderson, 'Criminalizing "Virtual" Child Pornography Under the Child Pornography Prevention Act: Is It Really What It “Appears to Be?', (2001) 35 U. RICH. L. Rev.393' $<$ http://scholarship.richmond.edu/lawreview/vol35/iss2/6>. accessed 27 December 2019

${ }^{25}$ Andrew Gilden, 'Punishing Sexual Fantasy' (2016) 58 William \& Mary Law Review.[419-491].

${ }^{26}$ Articles 74(2b) and 183.
} 
that all stakeholders define and regard terms in the same approach. In addition, legal concepts between states need to be harmonious if bilateral and international cooperation are to be impactful. The terms in the OPSC have been officially defined by the Committee, other treaty bodies and United Nations organizations. Given the need for conceptual clarity within, among and between states, the use of the official definitions is proposed. ${ }^{27}$

The Committee is particularly concerned about the widespread distribution and accessibility of child pornography through the Internet. It has strongly and consistently recommended that States Parties and the international community urgently combat the issue. Specific recommendations have been made regarding adoption of legislation on the obligations of Internet service providers in relation to child pornography. ${ }^{28}$ Indonesia enacted Electronic Information and Transaction Law in 2008. ${ }^{29}$ It was amended in 2016. It prohibits and criminalizes any person who deliberately and without rights distribute and/or transmit and/or make the electronic information and/or electronic document containing obscenity or sexual exploitation of the child accessible. ${ }^{30}$ However, it does not go further by defining child pornography.

Article 3 (1)(c) of the OPSC requires States Parties to criminalize 'producing, distributing, disseminating, importing, exporting, offering, selling or possessing for the above purposes child pornography as defined in Article 2.' Interpreted rigidly, according to the Article 3 (1)(c) of the OPSC, States Parties obliges to punish the possession of child pornography only when this possession is "for the above purposes", i.e. producing, distributing, disseminating, importing, exporting, offering or selling. However, the Committee has nonetheless urged State Parties

${ }^{27}$ UNICEF, Handbook on the Optional Protocol on the Sale of Children, Child Prostitution and Child Pornography (n 5).[5].

${ }^{28}$ UNICEF (n 5).[12]. See, for example, UN Committee on the Rights of the Child, the Concluding Observations of the Committee on the reports of Turkey (CRC/C/OPSC/TUR/CO/1, 9 June 2006, paras. 17-19); Viet Nam (CRC/C/OPSC/VNM/CO/1, 17 October 2006, paras. 10-11); Costa Rica (CRC/C/OPSC/CRI/CO/1, 2 May 2007, paras. 14-15); Sudan (CRC/C/OPSC/SDN/CO/1, 21 June 2007, paras. 23-24); France (CRC/C/OPSC/FRA/CO/1, 15 October 2007, paras. 16-17); and Chile (CRC/C/OPSC/CHL/CO/1, 18 February 2008, paras. 22-23).

${ }^{29}$ Entered into force on 21 April 2008.

${ }^{30}$ Articles 27(1) and 52. 
to prohibit simple possession. ${ }^{31}$ In this case, Pornography Law also prohibits and criminalizes the possession of child pornography. The perpetrator will be sentenced to a maximum of 4 (four) years imprisonment and / or a fine of a maximum of two billion IDR. ${ }^{32}$ Unfortunately, the explanatory note of the article 6 allows the possession of child pornography as long as it is for self-interests purposes or one's own private use. Learn from other country's experience, the U.S. Supreme Court considered that mere possession of child pornography could be criminalized in Osborne v. Ohio. In the case of Osborne, the Court considered the constitutionality of an Ohio statute that prohibited the possession of material representing children in the nude. It upheld the statute based on the conclusion that states have a compelling interest in protecting children. ${ }^{33}$ In addition, it can be a preventive effort as well in case access to such materials results further child abuse and exploitation. ${ }^{34}$

\section{Prioritize Prevention in Combatting Child Pornography}

Violence, including sexual violence are widely noticed as globally serious human rights problems. ${ }^{35}$ States are compelled to react to violence against

\footnotetext{
${ }^{31}$ - UNICEF (n 5).See, for example, UN Committee on the Rights of the Child, Consideration of Reports submitted by States Parties under the OPSC, the Concluding Observations of the Committee on the reports of Chile (CRC/C/OPSC/CHL/CO/1, 18 February 2008, paras. 23-24); Costa Rica (CRC/C/OPSC/CRI/CO/1, 2 May 2007, paras. 14-15 and 24-25).

- In contrast, the Council of Europe Convention on Cybercrime (2001) criminalizes "possessing child pornography in a computer system or on a computer-data storage medium" (Article 9(1)(e)). However, States Parties may reserve the right not to apply, in whole or in part, this provision (Article 9.4). The Council of Europe Convention on the Protection of Children against Sexual Exploitation and Sexual Abuse (2007) provides that States Parties obliges to criminalize the possession of child pornography, even though there is a provision that they may reserve the right not to apply, in whole or in part, provisions concerning the production and possession of pornographic material if this material consists exclusively of simulated representations or realistic images of a non-existent child or involves images that are produced and possessed by children over a certain age with their consent and solely for their own private use (Article 20(3)). (UNICEF, UNICEF (n 5).[54]

${ }^{32}$ Articles 6 and 32.

${ }^{33}$ Sara C. Marcy, 'Banning Virtual Child Pornography: Is There Any Way around Ashcroft v. Free Speech Coalition', (2003) 81N.C. L. Rev.2136'<http://scholarship.law.unc.edu/nclr/vol81/ iss $5 / 9>$.accessed 27 December 2019.

${ }^{34}$ Mihaela Astinova, 'The Crime of Child Pornography: European Legislative and Police Cooperation Initiatives' [2013] International and European Public Law Master Thesis, Tilburg University.[4].

${ }^{35}$ Nicola Henry and Anastasia Powel, 'Technology-Facilitated Sexual Violence: A Literature Review of Empirical Research' (2018) 19 Trauma, Violence, \& Abuse.[195-208].
} 
children as well as prevent violence before it takes place. ${ }^{36}$ According to Article 9 (1) of the OPSC, the OPSC requires States to adopt or strengthen, implement and disseminate laws, administrative measures, social policies and programmes to prevent the sale of children, child prostitution and child pornography. The Committee has highlighted the issue of the importance to address the root causes, such as poverty, underdevelopment and cultural attitudes, as well as the nature and extent of the problem. ${ }^{37}$

Particular attention shall be given to protect children who are especially vulnerable to the practices of sale of children, child prostitution and child pornography. There are many groups of children who are particularly vulnerable to violence include children with disabilities, orphaned children (including the millions of children who have lost parents to AIDS), children who are indigenous or belong to other marginalized groups, children living and/or working on the streets, children in institutions and detention, child refugees, child migrants and internally displaced children. In some settings, girls are particularly at risk of violence than boys, and vice versa. ${ }^{38}$ Some studies have also identified that poor family functioning and low-quality parent-child relationships, weak legal systems and/or ineffective policies to protect children, the absence of the biological mother, child marriage, or marriage before 18 years, as placing girls at risk of sexual violence by their partners, social norms and beliefs about gender equality may also affect the risk of sexual violence among girls. ${ }^{39}$

Besides determining potential causes for violence, it is also important to identify positive elements that can protect children against it. One of them is strong relationship in the family, particularly between parents and children. Furthermore,

36 IPU/ UNICEF, Handbook for Parliamentarians No. 13: Eliminating Violence against Children (s.n 2007). [30].

37 Laura Theytaz Bergman, Reporting on the OPSC and OPAC: A Guide for Non-Governmental Organizations (NGO Group for the Convention on the Rights of the Child 2010). [17].

38 IPU/ UNICEF (n 37).

39 Lauren Rumble, [et.,al.], 'Childhood Sexual Violence in Indonesia: A Systematic Review' (2018) XX Trauma, Violence, \& Abuse.[1-16]. 
the stable families is also a powerful weapon to prevent children from violence. ${ }^{40}$ As the first place where children have their upbringing and socialization, family has to be the safe environment for children's life. The family has to create the safe socialization which contributes to the formation of a healthy personality and preserve health of children; development of children's capacity to counter risks; development by a child of the values of a safety culture in the process of communication with different social systems; competences to overcome threat, etc. ${ }^{41}$

In the context of Indonesia, Article 15 Pornography Law states that every one must protect children from the influences of pornography and prevent children's access to information that contains pornography. According to Article 17 Pornography law, the central and local government are obliged to prevent the manufacture, dissemination and use of pornography. Furthermore, in Articles 18 and 19 provided that to prevent as referred to in Article 17, both central and local government have the authorities to:

a. terminate the network for the manufacture and dissemination of pornographic products or pornographic services, including blocking pornography through the internet;

b. supervise the making, dissemination and use of pornography; and

c. cooperate and coordinate with various parties, both from within and from abroad (for central government), in the prevention of the creation, dissemination and use of pornography.

d. developing a system of communication, information and education in the context of preventing pornography in its territory (for local government).

Based on Article 20, the Pornography Law also argues that society can participate in preventing the creation, dissemination and use of pornography. This article does not explicitly encourage people to participate in the prevention of pornography since it uses the term "can". Thus, this depends on the one's will whether he or she participates in preventing the creation, dissemination and use of pornography. While Article 9(2) of the OPSC argues that States Parties shall

\footnotetext{
${ }^{40}$ IPU/ UNICEF (n 36).ibid. [31].

41 Natalya V. Goltsova and Elena V. Yakovleva, 'The Content of Safe Socialization Of The Younger Teenager in A Family Environment' (2018) year VI Astra Salvensis - review of history and culture.[21-28].
} 
promote awareness in the public at large, including children, through information by all appropriate means, educating and training, about the preventive measures and harmful effects of the effects of the offences referred to in the OPSC. In fulfilling their obligation under this Article, States Parties shall encourage the participation of the community and, in particular, children and child victims, in such information and education and training programs, including at the international level.

To implement the provisions of Pornography Law, the government stipulated Government Regulation Number 40 Year 2011 on Guidance, Assistance, and Recovery of Children Who Are Victims or Perpetrators of Pornography. According to this Government Regulation, Children who are victims of pornography are children who experience trauma or suffering as a result of pornography. On the other hand, the Children who become pornography perpetrators are children who commit pornography crimes. Unfortunately, this government regulation does not provide the prevention approach to child pornography. It only addresses the guidance, assistance, and recovery after the crime occurred.

In addition, to improve the effectiveness of the implementation of the Pornography Law, the President Regulation Number 25 Year 2012 on the Task force in Preventing and Responding to Pornography was enacted. The task force is a coordinating agency which in charge in coordinating the prevention and respond to pornography. According to this president regulation, the task force has some tasks as mentioned below:

a. to coordinate the efforts of prevention and respond to pornography problems;

b. to monitor the implementation of prevention and respond to pornography;

c. to carry out socialization, education and cooperation on prevention and respond to pornography; and

d. to carry out the evaluation and report.

The position of this task force is in the capital city of Indonesia, but it can be formed in the provinces as well as in regencies or cities. The membership structure of the task force consists of the chairperson and members. The Chairperson is the Coordinating Minister for People's welfare while the daily Chairperson is the Minister of Religion. The Members of the Task Force consists of Minister of 
Communication and Information Technology, Minister of Women's Empowerment and Child Protection, Minister of Law and Human Rights, Minister of Education and Culture, Minister of Home Affairs Minister of Industry, Minister of Trade, Minister of Tourism and Creative Economy, Minister of Health, Minister of Social Affairs, Minister of Youth and Sports, Head of the Indonesian National Police, Attorney General of the Republic of Indonesia, Chairperson of the Indonesian Broadcasting Commission and Chairperson of the Film Censorship Institute.

In 2018, a meeting to draft the 5 (five) year annual report of the Task Force was held. At the meeting, the Ministry of Communication and Information said that there had been a lot of blocking of pornographic contents. The Ministry also promoted digital literacy programs that educate public about internet access intelligently and safely to prevent the effects of pornography. ${ }^{42}$ Nevertheless, the government still need to prioritize the prevention through adopting the holistic approach which determine the root causes for child pornography, as well as identify the positive factors that can protect children against it.

\section{Conclusion}

With regard to the conformity of law of Indonesia concerning prohibition of child pornography with the OPSC, Indonesia is facing the issue of the incompatibility of its respective national law with the OPSC. The domestic law lacks the definition of child pornography. It may cause some offences which shall be categorized as child pornography under the OPSC cannot be criminalized under the domestic law. Thus, it is important to ensure that all stakeholders define and regard the term in the same approach. Furthermore, Indonesian law still allows the possession of child pornography as long as it is for self-interests purposes or one's own private use, in spite of the fact that the Committee has prompted State Parties to criminalize

42 Ndi, 'Penyusunan Laporan 5 Tahunan Gugus Tugas Pencegahan Dan Penanganan Pornografi (GTP3)' (5 Annual Report Compilation of the Task force in Preventing and Responding to Pornography (kominfo 2018). <https://aptika.kominfo.go.id/2018/10/fgd-penyusunan-laporan5-tahunan-gugus-tugas-pencegahan-dan-penanganan-pornografi-gtp3/>accessed 19 June 2020 
simple possession. By prohibiting the simple possession of child pornography, in some cases a State may prevent children from further abuse or exploitation. For that reasons, the Government of Indonesia needs to review its respective national law concerning prohibition of child pornography.

In addition, the Government should consider the importance of prioritizing the prevention of child pornography by applying the holistic approach, addressing the contributing factors such as poverty, underdevelopment and cultural attitudes, as well as the nature and extent of the problem, giving the particular attention to the vulnerable group of children, as well as identifying positive elements that can protect children against child pornography. Additionally, the efforts to raise public awareness are needed to protect the children from the dangers of child pornography.

\section{Bibliography}

Andrew Gilden, 'Punishing Sexual Fantasy' (2016) 58 William \& Mary Law Review.

Binford W, 'A Global Survey of Country Efforts to Ensure Compensation for Child Pornography Victims’ (2015) 13 Ohio State Journal of Criminal Law.

Combating "Child Abuse Images" Through Committed, Transversal And Internationally Coordinated Action, Report of the Social, Health and Family Affairs Committee, 2011 in Mihaela Astinova, The Crime of Child Pornography: European Legislative and Police Coop (International and European Public Law Master Thesis, Tilburg University 2013).

Indonesian Criminal Code.

IPU/ UNICEF, Handbook for Parliamentarians No. 13: Eliminating Violence against Children (s,n 2007).

Jnp/Dal, 'KPAI: 1.940 Anak Jadi Korban Kejahatan Online Sejak 20172019' (KPAI: 1,940 Children Become Victims of Cybercrimes within 2017-2019)' (CNN Indonesia, 2020) <https://www.cnnindonesia.com/ teknologi/20200210131134-185-473240/kpai-1940-anak-jadi-korbankejahatan-online-sejak-2017-2019> accessed 17 June 2020.

Juliane A. Kloess, [et.,al.], 'Online Child Sexual Exploitation: Prevalence, Process, and Offender Characteristics' (2014) 15 Trauma, Violence, \& Abuse. 
Laura Theytaz Bergman, Reporting on the OPSC and OPAC: A Guide for NonGovernmental Organizations (NGO Group for the Convention on the Rights of the Child 2010).

Lauren Rumble, [et., al], 'Childhood Sexual Violence in Indonesia: A Systematic Review' (2018) XX Trauma, Violence, \& Abuse.

Law Number 13 Year 2003 on Labour.

Law Number 11 Year 2008 on Electronic Information and Transaction.

Law Number 19 Year 2016 on the Amendment of Law Number 11 Year 2008 on Electronic Information and Transaction.

Law Number 44 Year 2008 on Pornography.

Law Number 23 Year 2002 on Child Protection.

Law Number 35 Year 2014 on the Amendment of Law Number 23 Year 2002 on Child Protection.

Lorraine Radford, [et., al]., Preventing and Responding to Child Sexual Abuse and Exploitation: Evidence Review (UNICEF 2015).

Maikada Harjono, 'KPAI: Pornografi Dan Cyber Crime Masuk Tiga Besar Pengaduan Anak' (KPAI: Pornography And Cybercrimes Are In The Big Three Cases Reported Involving Children)' (kominfo, 2020) <https://aptika. kominfo.go.id/2020/02/kpai-pornografi-dan-cyber-crime-masuk-tiga-besarpengaduan-anak/>. accessed 17 June 2020.

Mihaela Astinova, 'The Crime of Child Pornography: European Legislative and Police Cooperation Initiatives' [2013] International and European Public Law Master Thesis, Tilburg University.

Natalya V. Goltsova and Elena V. Yakovleva, 'The Content of Safe Socialization Of The Younger Teenager in A Family Environment' (2018) year VI Astra Salvensis - review of history and culture.

Ndi, 'Penyusunan Laporan 5 Tahunan Gugus Tugas Pencegahan Dan Penanganan Pornografi (GTP3)' (5 Annual Report Compilation of the Task force in Preventing and Responding to Pornography, (kominfo, 2018) $<\mathrm{https}$ :// aptika.kominfo.go.id/2018/10/fgd-penyusunan-laporan-5-tahunan-gugustugas-pencegahan-dan-penanganan-pornografi-gtp3/> accessed 19 June 2020. 
Nicola Henry and Anastasia Powel, 'Technology-Facilitated Sexual Violence: A Literature Review of Empirical Research' (2018) 19 Trauma, Violence, \& Abuse.

Sara C. Marcy, 'Banning Virtual Child Pornography: Is There Any Way around Ashcroft v. Free Speech Coalition', 81N.C. L. Rev.2136' (2003).

Sonia Livingstone and Monica E. Bulger, 'A Global Research Agenda for Children's Rights in the Digital Age' (2014) 8 Journal of Children and Media.

Suzanne Ost, Child Pornography and Sexual Grooming: Legal and Social Responses (Cambridge University Press 2009).

The Convention on the Rights of the Child (1989).

The Council of Europe Convention on Cybercrime (2001).

The Council of Europe Convention on the Protection of Children against Sexual Exploitation and Sexual Abuse (2007).

The Optional Protocol to the Convention on the Rights of the Child on the Sale of Children, Child Prostitution and Child Pornography (2000).

Trevor Buck, International Child Law (Routledge 2014).

UNICEF, Implementation Handbook for the Convention on the Rights of the Child (UNICEF Regional Ofice for Europe 2007).

- Handbook on the Optional Protocol on the Sale of Children, Child Prostitution and Child Pornography (UNICEF IRC 2009).

—_, 'Sexual Violence against Children' (UNICEF, 2018) < https://www.unicef. org/protection/57929_58006.html $>$ accessed 17 June 2020.

United Nation Human Rights'UN Treaty Body Database’.( United Nation Human Rights,) < <ttps://tbinternet.ohchr.org/_layouts/15/TreatyBodyExternal/ TBSearch.aspx $>$ accessed 17 June 2020.

United Nations Treaty Collection, 'Human Right: 11. c Optional Protocol to the Convention on the Rights of the Child on the Sale of Children, Child Prostitution and Child Pornography' (United Nations Treaty Collection, 2000) $<$ https://treaties.un.org/Pages/ViewDetails.aspx?src=TREATY\&mtdsg_ no=IV-11-c\&chapter=4\&clang=_en $>$ accessed 14 May 2020.

Wade T. Anderson, 'Criminalizing "Virtual” Child Pornography Under the Child 
Pornography Prevention Act: Is It Really What It “Appears to Be?', (2001) 35 U. RICH. L. Rev.393'.

Zendy Prameswari, 'Prohibition of Sale of Children: Legal Consequences of the Ratification of the Optional Protocol on the Sale of Children, Child Prostitution and Child Pornography by Indonesia.' [2011] Master Thesis, International Human Rights and Humanitarian Law Program, European University Viadrina Frankfurt (Oder).

HOW TO CITE: Zendy Wulan Ayu Widhi Prameswari, 'Prohibition of Child pornography: Enhancing Child Protection in Indonesia' (2020) 35 Yuridika. 